\title{
Endocronological and behavioural effects of $p$-chlorophenylalanine (PCPA) oral administration to broody turkey hens (Meleagris gallopavo)*
}

\author{
D. Guémené ${ }^{1}$ and R.J. Etches ${ }^{2}$ \\ 1 INRA, Station de Recherches Avicoles, Nouzilly 37380 Monnaie, France; \\ 2 Department of Animal and Poultry Science, University of Guelph, Guelph, Ontario, \\ N1G-2W1 Canada
}

(received 6 January 1989, accepted 27 June 1989)

Summary - Changes in plasma levels of prolactin and LH, feed intake, water consumption, behavioural pattern and ovarian activity were recorded after oral administration of PCPA to broody turkey hens. A decrease in prolactin concentration was measured, from day 3 , in 3 out of the 5 birds treated with $100 \mathrm{mg}$ PCPA $\mathrm{kg}$ body weight (BW) for 3 consecutive days. In these hens, broodiness was disrupted on day 6 and feeding activity subsequently increased to levels of photorefractory hens. Neither LH concentrations nor ovarian activity were affected after treatment with PCPA. Moreover, PCPA treatment was ineffective at a $50 \mathrm{mg} / \mathrm{kg} \mathrm{BW}$ dose.

These results confirm that a serotoninergic mechanism is probably involved in prolactin release and moreover suggest that prolactin is implicated in maintaining broody behaviour. However, the reductions in the plasma concentration of prolactin induced by PCPA were not sufficient to restore the hypothalamic-hypophyseal-ovarian axis to a physiological status characteristic of the laying hen. Therefore, PCPA does not appear to be a useful method of treating broodiness in commercial turkey hens.

turkey hen — broodiness - prolactin — laying — feeding activity

Résumé - Conséquences comportementales et endocrinologiques d'une administration orale de p-chlorophénylalanine (PCPA) à des dindes couveuses (Meleagris gallopavo). $L$ 'évolution de la concentration plasmatique de prolactine et de $L H$, de la consommation d'aliment et d'eau, ainsi que de l'expression du comportement d'incubation est observée après administration orale de PCPA à des dindes couveuses. Une décroissance du niveau de prolactine circulante est mesurée à partir du jour 3, chez 3 des 5 dindes ayant reçu une dose de $100 \mathrm{mg} P C P A \mathrm{~kg}$ de poids vif (PV) durant 3 jours consécutifs. Ces dindes ont ultérieurement interrompu la couvaison (jour 6 ) et accru leur activité alimentaire à un niveau comparable à celui des dindes photoréfractaires. En revanche, la concentration plasmatique de $\mathrm{LH}$ et l'activité ovarienne n'ont pas été affectées par l'administration de PCPA. En outre, le PCPA est sans effet dans nos conditions expérimentales à la dose de $50 \mathrm{mg} / \mathrm{kg} P V$.

* These results were partially presented at the XVIII World Poultry Congress and Exhibition, Sept. 1988, Nagoya, Japan. 
Cette étude confirme qu'un mécanisme sérotoninergique est probablement impliqué dans le contrôle de la sécrétion de la prolactine et suggère, en outre, que cette hormone est associée au maintien du comportement dincubation. Par contre, la décroissance du taux de prolactine circulante, consécutive à l'administration de PCPA, ne restaure pas l'état fonctionnel de l'axe hypothalamus-hypophyse-ovaire, caractéristique de la dinde pondeuse. En conséquence, l'utilisation du PCPA afin d'interrompre la couvaison au sein des élevages n'est pas à encourager dans l'état actuel des connaissances.

dinde - prolactine - LH - couvaison - ponte - ingestion

\section{INTRODUCTION}

Pharmacological treatment of broody turkey hens with PCPA, an inhibitor of serotonin synthesis, induced an increase in $\mathrm{LH}$ levels and a decrease in prolactin concentrations, disruption of broody behaviour and resumption of lay (El Halawani et al., 1983). Similarly, the release of LH was inhibited by the intraventricular injection of serotonin and was stimulated by intraperitoneal administration of PCPA in the laying hen (Sakurai et al., 1986). However, the systemic injection of quipazine maleate (an agonist of serotonin) and the intraventricular injection of serotonin had no effect on plasma LH levels in female turkeys (Hargis and Burke, 1984). Furthermore, the administration of PCPA in chickens resulted in a decrease in $\mathrm{LH}$ levels (Buonomo et al., 1981) and no change in prolactin concentration (Rabii et al., 1981). However, as El Halawani et al. (1983) combined administrations of PCPA with nest ejections, a technique which is traditionally used to prevent broodiness in commercial flocks, the question arises whether the effects reported in their study are due to the actions of PCPA alone or are the consequence of a synergistic effect of the pharmacological and the traditional treatments.

The purpose of this experiment was, therefore, to investigate the effects of
PCPA alone on the maintenance of broody behaviour and the resumption of lay in turkey hens, and to further clarify the temporal and functional relationships between disruption of broodiness, resumption of lay, changes in prolactin and $\mathrm{LH}$ concentrations and feeding activity.

\section{MATERIALS AND METHODS}

\section{Birds}

Hybrid Turkeys Inc., large white turkey hens ( $n$ $=44)$ in their first egg-laying cycle were removed from a commercial flock when showing first symptoms of broody behaviour and then transferred to individual floor cages $(1.65 \times 0.75 \mathrm{~m})$ containing a nest box. The birds were maintained under a 15-h photoperiod $(4.00-19.00 \mathrm{~h})$ and a minimum light intensity of 40 lux. Broodiness was then encouraged by providing 10 eggs per bird. Hens were considered to be broody if they exhibited nest defense behaviour, gathered and incubated the eggs.

Twenty-two of these birds did not express this behaviour under our experimental conditions. They were subsequently classified as photorefractory and included in the experiments described below as non-broody out-of-lay controls. The 22 remaining hens which expressed broody behaviour were randomly assigned to the control $(n=12)$ or the treated group ( $n=10 ; 5$ per dose). 


\section{Experimental approach}

A test of broodiness expression, which consisted of 5 daily checks of the previously described criteria, was carried out during the pre-treatment phase of 6 days (day -6 to 0 ) and the experimental period of 22 days (day 0 to 21). Hens were randomly assigned to treatments which consisted of oral administration of 00 gelatin capsules containing PCPA (D-L, p-chlorophenylalanine crystalline, Sigma, St. Louis, MO, USA) at doses of 50 or 100 $\mathrm{mg} / \mathrm{kg}$ body weight/day for 3 consecutive days (days : $0,1,2$ ). Empty 00 gelatin capsules were administered to broody control hens.

Changes in plasma prolactin and $\mathrm{LH}$ concentrations, expression of broodiness, feeding activity and egg production were recorded for the 28-day period of the experiment. Hens were fed ad libitum on a commercial diet and both feed intake and water consumption were recorded daily. Oviduct and ovarian weights were recorded at the end of the trial. Blood samples $(3-4 \mathrm{ml})$ were withdrawn from the wing vein into heparinized syringe between 10.00 a.m. and 12.00 a.m. before drug administration (days : $-6,-3,0$ ) and after the initiation of the treatment (days : $1,2,3,4,5,7,10,14,17,21)$. Blood samples were also collected from photorefractory hens on days $-6,-3,0,7,14$ and 21 . Plasma was separated after centrifugation $(2000 \mathrm{~g}, 10 \mathrm{~min}$, $4{ }^{\circ} \mathrm{C}$ ) and stored at $-20^{\circ} \mathrm{C}$ until required for radioimmunoassay.

\section{Radioimmunoassays}

\section{Prolactin}

Prolactin concentrations were assayed in duplicate $0.1 \mathrm{ml}$ aliquots of plasma according to Etches and Cheng (1982). The mean intraassay variation was $7.1 \%$ and interassay variation for the $\mathbf{5}$ assays needed for this study was $7.8 \%$.

\section{Luteinizing hormone}

$\mathrm{LH}$ concentrations were measured in duplicate $0.1 \mathrm{ml}$ aliquots of plasma using the assay described by Etches et al. (see Zadworny,
1985). The mean intraassay variation was $11.3 \%$ and interassay variation for the 5 assays required for this study was $12.6 \%$.

\section{Statistical analysis}

Hormonal data from the treated and the control groups were subjected to the analysis covariance (ANCOVA) using the SAS general linear model procedure (SAS Institute Inc., 1986). Concentrations measured on day 0 were used as covariates. Hormonal data from the treated groups were also compared with data from the photorefractory group and differences were estimated by the Scheffe $F$ test. Daily mean feed intake and water consumption were compared by analysis of variance using Waller Duncan's k-ratio t-test (SAS Institute Inc., 1986).

It is appreciated that the small sample size renders statistical comparisons questionable, however all statements below were made on the basis of the observed results and statistical analysis was included for the sake of completeness.

\section{RESULTS}

\section{Behaviour}

Disruption of broody behaviour occured on day 6 in 3 out of the 5 hens treated with $100 \mathrm{mg} \mathrm{PCPA} / \mathrm{kg}$ BW. All other treated or control broody hens maintained broodiness during the entire trial. None of the initially broody hens resumed laying during the 28 days of the experimental period. Furthermore, ovarian and oviduct regression, as indicated by post-mortem examination, were observed in all hens, except for one hen (No. 54) treated with $50 \mathrm{mg}$ PCPA $\mathrm{kg}$ BW, which laid continuously throughout the experiment 
(21 eggs in 28 days) while fully expressing broody behaviour.

\section{Prolactin concentrations}

High or low, but stable levels in plasma prolactin were measured throughout the study in broody and photorefractory controls respectively (Fig. 1). No change in mean plasma prolactin concentrations was observed after oral administration of $50 \mathrm{mg}$ PCPA/kg BW (data not shown), whereas a decrease in plasma prolactin concentrations was measured from day 3 to day 21 in the 3 hens which disrupted broody behaviour after administration of the $100 \mathrm{mg}$ PCPA/kg BW dose (Fig. 1). The differences between the plasma prolactin concentrations of these birds and those of the broody control hens was significant $(P<0.05)$ from day 7 onward. Subsequently, by the end of the trial, the differences between the plasma prolactin concentrations of these birds and those of the photorefractory hens were no longer significant $(P>0.05)$. No change in plasma prolactin levels was found in the 2 hens which maintained broody behaviour.

\section{LH concentrations}

No change in plasma $\mathrm{LH}$ concentrations was observed after administration of PCPA at either dose, either for the entire group or in the birds in which broodiness was disrupted (Fig. 2).

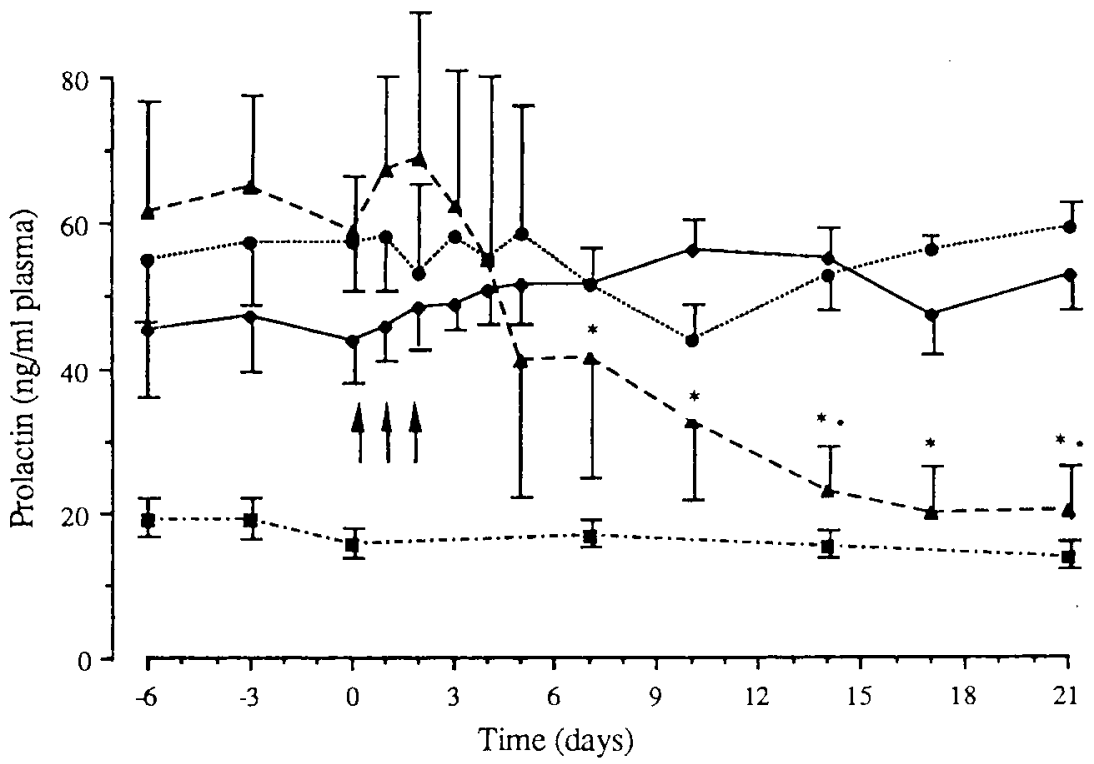

Fig. 1. Changes in plasma concentrations of prolactin in control broody ( $n=12$; $\longrightarrow$ ),

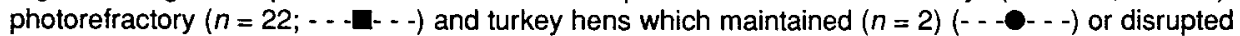
$(n=3)\left(----^{-}-\right)$broody behaviour following treatment with $100 \mathrm{mg} \mathrm{PCPA} / \mathrm{kg}$ b.w. for 3 consecutive days starting on day $0(T)$ (means \pm SEM). ${ }^{*}$ Significantly different from broody control group $(P<$ $0.05)$. Non-significantly different from photorefractory group $(P>0.05)$. 


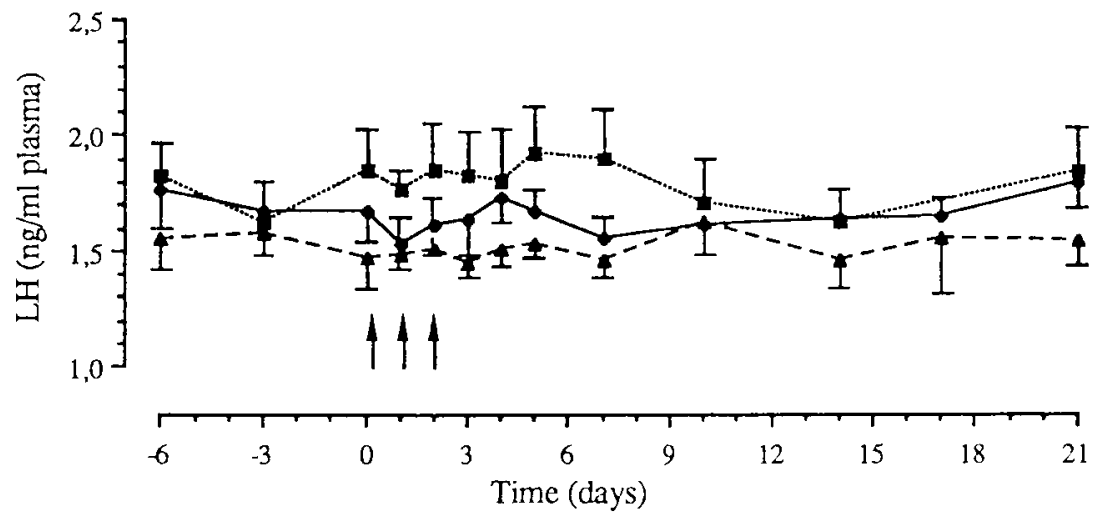

Fig. 2. Changes in plasma concentrations of $\mathrm{LH}$ in broody turkey hens from a control group $(n=12$; $-\rightarrow$ ) and following treatment with PCPA at doses of 50 (- - - - ) or $100 \mathrm{mg} / \mathrm{kg}$ b.w. (- - - - -) for 3 consecutive days starting on day $O(\uparrow)(n=5$; means \pm SEM).

\section{Feed intake and water consumption}

Daily water consumption and feed intake records showed that broody controls were eating and drinking as much as the photorefractory hens at the beginning of the trial. However, significant differences
$(P<0.05)$ between the 2 groups were found throughout the experiment since feeding activity decreased continuously in the broody control group, while it increased in the photorefractory group (Figs 3, 4). Feeding activity of the broody hens treated with a $50 \mathrm{mg} / \mathrm{kg}$ BW dose

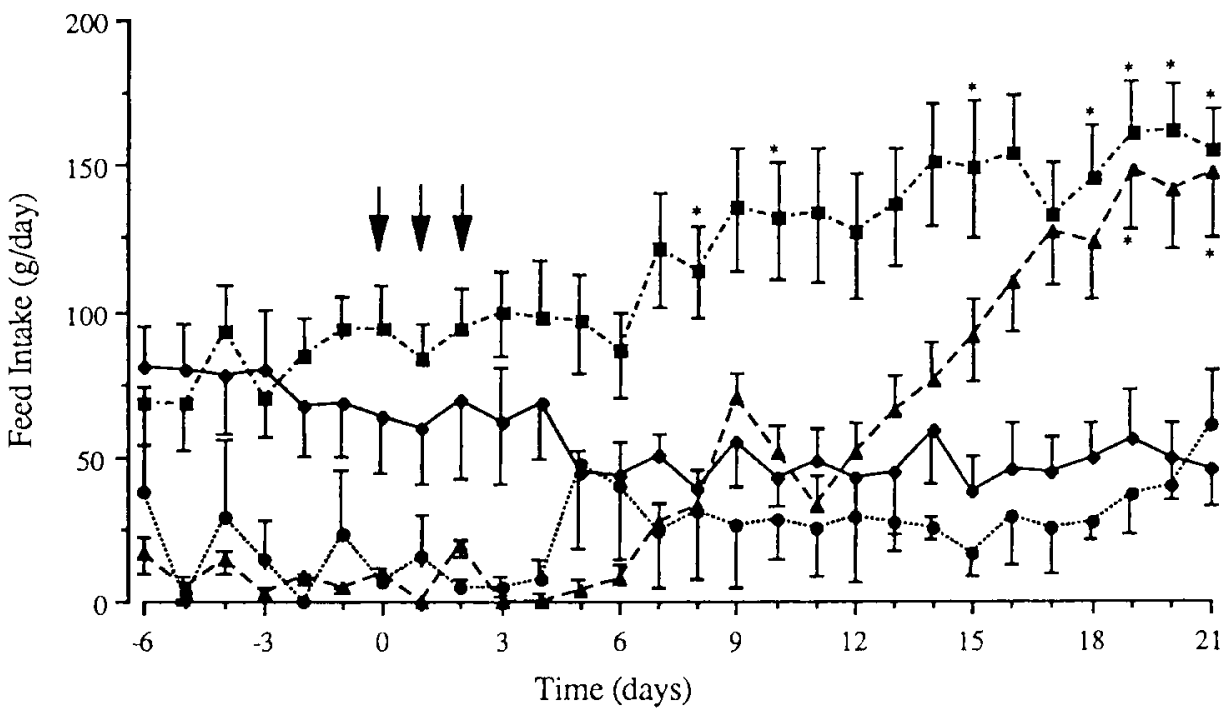

Fig. 3. Changes in feed intake ( $g /$ day) in broody control $(n=12$; $-\longrightarrow)$, photorefractory $(n=22$;

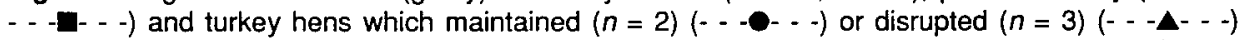
broody behavior following treatment with $100 \mathrm{mg}$ PCPA/kg b.w. for 3 consecutive days starting on day $O(\downarrow)$ (means \pm SEM). * Significantly different from broody control group $(P<0.05)$. 


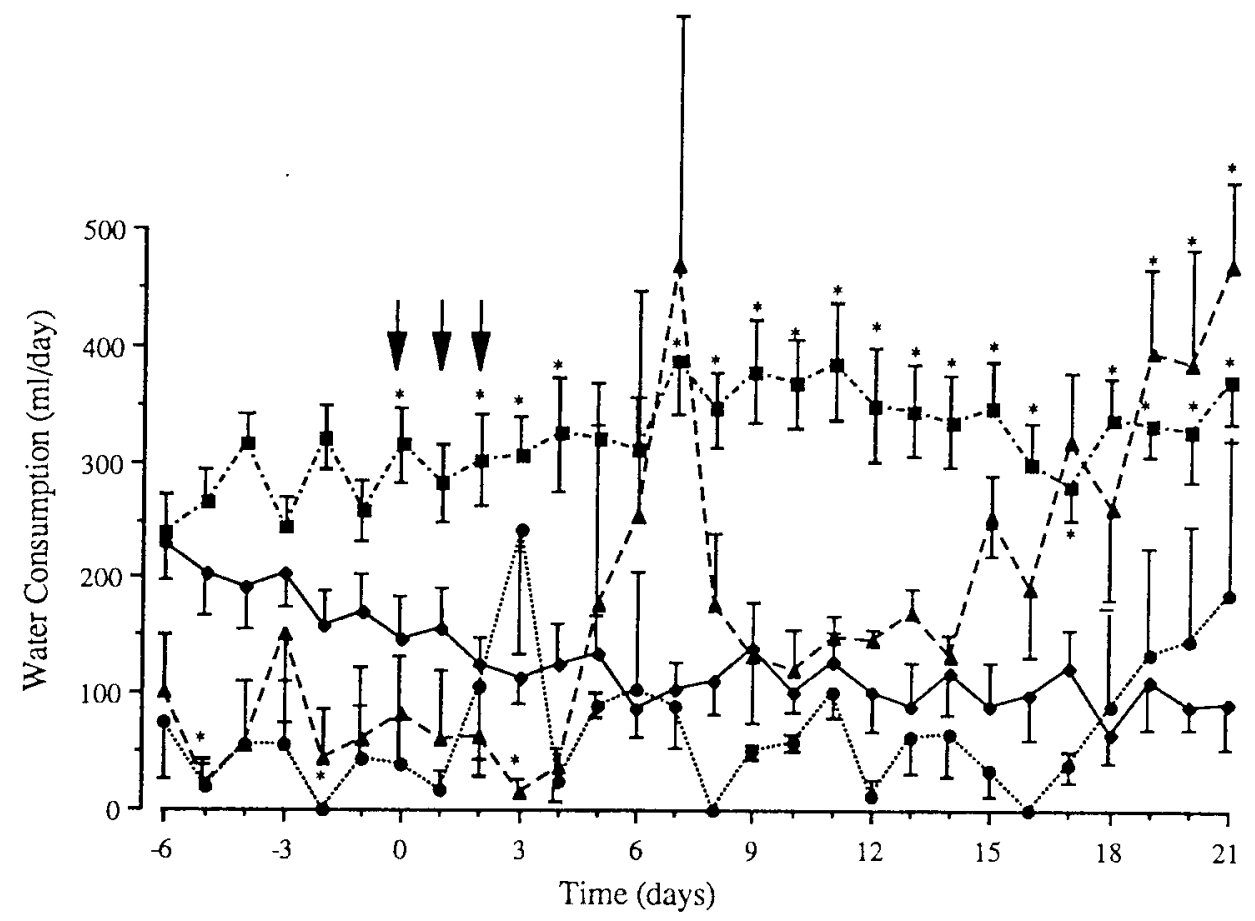

Fig. 4. Changes in water consumption (ml/day) in broody control $(n=12 ;-\downarrow)$, photorefractory

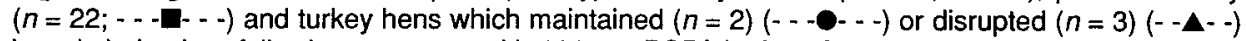
broody behaviour following treatment with $100 \mathrm{mg}$ PCPA/kg b.w. for 3 consecutive days starting on day $0(\$)$ (means \pm SEM). * Significantly different from broody control group $(P<0.05)$.

was very similar to that of control broody hens (data not shown). On the other hand, feeding activity for the hens treated with a $100 \mathrm{mg} / \mathrm{kg} \mathrm{BW}$ was at a lower level than controls during the pre-treatment period (Figs. 3, 4). Nevertheless, significant increases first in water consumption and thereafter in both water consumption and feed intake were observed following disruption of broodiness (Figs. 3, 4). Consequently, by the end of the trial, these birds were eating and drinking as much as the photorefractory hens $(320 \mathrm{ml} /$ day and 130 $\mathrm{g} /$ day) while the feeding activity of the birds which maintained broodiness was comparable to that of control broody hens.

\section{DISCUSSION}

The present data only partially confirm the previous report of El Halawani et al. (1983) on the effects of PCPA administered to broody turkey hens. Indeed, we did not observe any of the effects reported by these authors after treatment with a $50 \mathrm{mg}$ PCPA $/ \mathrm{kg}$ dose. Alternately, broodiness was disrupted in a proportion of hens $(3 / 5)$ following administration of a $100 \mathrm{mg}$ PCPA/kg dose. Furthermore, it is evident from the data in Figure 1 that plasma concentrations of prolactin measured in these 3 hens started to decline before any behavioural indication of broodiness disruption was 
observed. This relationship supports the hypothesis that high concentrations of prolactin are directly responsible for the maintenance of broody behaviour and argues against the concept that changes in the plasma levels of prolactin are a consequence of changes in behaviour. This conclusion is further supported by the observation that plasma prolactin levels remained unchanged in hens that received 50 or $100 \mathrm{mg} / \mathrm{kg}$ of PCPA but maintained broody behaviour. Similar results were also observed after an i.p. injection of $200 \mathrm{mg} P C P A / k g ~ B W$ (Guémené and Etches, unpublished observations).

Another major difference between the current results and those of El Halawani et al. (1983) is the absence of any increase in plasma $\mathrm{LH}$ levels after administration of PCPA at either dose, even in the birds in which broodiness was disrupted (Fig. 2). Consequently, ovarian activity failed to recommence following the termination of broody behaviour. These differences in response may be related to the difference in the strains of turkey hens used in each study, but are more likely due to the difference in the experimental design. Thus, El Halawani et al. (1983) combined administration of PCPA with nest ejection, whereas we allowed the hens, which were singly penned, to continue brooding their eggs without interruption. Furthermore, although EI Halawani et al. (1983) used hens which had fully expressed broody behaviour for $4-6$ days, they resumed lay after a short delay. This may indicate that hens were treated at a stage where complete regression of the reproductive tract had not yet taken place since, in the turkey hen, recrudescence of the yolk-filled hierarchy of follicles requires about 12 days for completion (Haller and Cherms, 1961; Nestor et al., 1970). Alternatively, if recrudescence began when broodiness was interrupted in our study, an increase in ovarian weight should have been observed when the hens were autopsied 21 days after PCPA treatment started. However, both ovarian and oviduct weights indicate that ovarian activity had not resumed and that regression of the gonad was complete in all but one hen. Although observations of hens that lay eggs while appearing broody are not common, they have been reported previously (Burke et al., 1981; Proudman and Opel, 1981; Lea et al., 1981; Bacon et al., 1983; Zadworny, 1985). These observations thus indicate that broody behaviour and egg production are not mutually exclusive events. Further investigation of this unusual juxtaposition of reproductive states may thus be warranted in the search for effective ways of preventing the antigonadal effects of broody behaviour.

Feed and water consumption in broody turkey hens decline to very low levels and it has been suggested that this metabolic change may be a cause of the concurrent increase in the plasma concentration of prolactin (Zadworny et al., 1985). The data presented in Tables I and II do not support this hypothesis since the change in feed and water intake that followed the disruption of broodiness occured when plasma prolactin was at lower levels. These data are consistent with those of Zadworny et al. (1985), who showed that increasing nutrient intake by force feeding did not lower plasma levels of prolactin in broody turkey hens.

In conclusion, our results only partially confirm those of El Halawani et al. (1983), and we suggest that part of the properties attributed to PCPA may possibly be due to a synergistic effect of pharmacological and traditional treatments. Thus, none of the initially out-of-lay broody hens resumed laying during the 28 experimental days. Since the objective of any 
broody treatment program is to reinitiate lay, these data indicate that under the conditions of this experiment, PCPA does not appear to be a useful method of treating broodiness in turkey hens. Nevertheless, the present data confirm that a serotoninergic mechanism is probably involved in prolactin release and suggest that prolactin is actively implicated in maintaining broody behaviour. On the other hand, changes in prolactin concentrations and feeding activity associated with the disruption of broodiness are not directly dependent.

\section{ACKNOWLEDGMENTS}

This work was supported in part by the Natural Sciences and Engineering Research Council of Canada, the Ontario Ministry of Agriculture and Food and Hybrid Turkeys Inc., Kitchener, Ontario, Canada. Our thanks are extended to Dr. F.J. Cunningham for the gift of chicken LH.

\section{REFERENCES}

Bacon W.L., Burke W.H., Nestor K.E. \& Brown K.I. (1983) Influence of genetic increases in egg production on traits associated with broodiness in turkeys. Poult. Sci. 62, 24602473

Buonomo F.C., Rabii J. \& Scanes C.G. (1981) Aminergic involvement in the control of luteinizing hormone secretion in the domestic fowl. Gen. Comp. Endocrinol. 45, 162-166

Burke W.H., Dennison P.T., Silsby J. \& EI Halawani M.E. (1981) Serum prolactin levels of turkey hens in relation to reproductive function. Adv. Physiol. Sci. 33, 109-116

El Halawani M.E., Silsby J.L., Ferher S.C. \& Behnke E.J. (1983) Reinitiation of ovulatory cycles in incubating female turkeys by an inhibitor of serotonin synthesis, p-chlorophenylalainine. Biol. Reprod. 28, 221-228

Etches R.J. \& Cheng K.W. (1982) A homologous radioimmunoassay for turkey prolactin : changes during the reproductive and ovulation cycle. Poult. Sci. 61, 1354-1362

Haller R.W. \& Cherms F.L. (1961) A comparison of several methods for terminating broodiness in broad breasted turkeys. Poult. Sci. 40, 155-163

Hargis B.M. \& Burke W.H. (1984) Prolactin and luteinizing hormone levels of prelaying, laying and postlaying turkey hens following central administration of serotonin and peripheral administration of quipazine maleate. Gen. Comp. Endocrinol. 55, 12-19

Lea R.W., Dods A.S.M., Sharp P.J. \& Chadwick A. (1981) The possible role of prolactin in regulation of nesting behaviour and the secretion of luteinizing hormone in broody bantams. J. Endocrinol. 91, 89-97

Nestor K.E., Bacon W.L. \& Renner P.A. (1970) Ovarian follicular development in egg and meat type turkeys. Poult. Sci. 50, 775-780

Proudman J.A. \& Opel H. (1981) Turkey prolactin : validation of a radioimmunoassay and measurement of changes associated with broodiness. Biol. Reprod. 25, 573-580

Rabii J., Buonomo F. \& Scanes C.G. (1981) Role of serotonin in the regulation of growth hormone and prolactin secretion in the domestic fowl. J. Endocrinol. 90, 355-358

Sakurai H., Kawashima M., Kamiyoshi M. \& Tanaka K. (1986) Effect of serotonin and Bendorphin on the release of luteinizing hormone in the hen (Gallus domesticus). Gen. Comp. Endocrinol. 63, 24-30

Zadworny D. (1985) Studies on the relationship of prolactin to reproductive function in turkey breeder hens. PhD. thesis, University of Guelph, Canada, pp. 176

Zadworny D., Walton J.S. \& Etches R.J. (1985) The relationship between plasma concentrations of prolactin and consumption of feed and water during the reproductive cycle of the domestic turkey. Poult. Sci. 64, 401-410 